\title{
Bacterial resistance to oxytetracycline in different life stages of Indian freshwater carp aquaculture system
}

\author{
Singh A.K. ${ }^{1}$, Rathore G. ${ }^{2}$, Singh V. ${ }^{2}$, Mani I. ${ }^{2}$, Singh R.K. ${ }^{*}$, Mishra S.K. ${ }^{4}$, Mishra B.N. ${ }^{3}$, \\ Verma O.P. \\ ${ }^{1}$ Department of Molecular Biology and Genetic Engineering, Allahabad Agricultural Institute-Deemed University \\ ${ }^{2}$ Division of Microbiology and Quarantine section, National Bureau of Fish Genetic Resources \\ ${ }^{3}$ Department of Biotechnology, Institute of Engineering and Technology \\ ${ }^{* 4}$ Department of Biotechnology, IMS Engineering College, Ghaziabad, Email: rksingh.iitr@hotmail.com
}

\begin{abstract}
In India antibiotics are frequently used for preventing and controlling bacterial pathogens in carp aquaculture system, yet no studies have been performed to evaluate the ecological impact of its intensive and prolonged use. In this work the frequency of oxytetracycline-resistant bacteria from water, palletized feed and different life stages of fish from Indian freshwater carp aquaculture system as well as the level of resistance of selected strains was investigated. Viable as well as antibiotic-resistant bacterial counts were performed by spread plate method in culture media supplemented with the oxytetracycline. Sixty two resistant Gram negative isolates which represented the oxytetracycline-resistant bacterial population, were randomly selected on nutrient agar supplemented with oxytetracycline $(50 \mu \mathrm{g} / \mathrm{ml})$ from carp farms and feed pellet samples. Among these bacterial isolates Flavobacterium (21\%), Alcaligenes (14.5\%), Aeromonas (11\%), Pseudomonas (10\%) and Enterobacteriace (19\%) were the most frequent. The Escherichia, Serratia, Citrobacter, Enterobacter, Shigella and Proteus from Enterobacteriace were recovered. Twelve isolates of oxytetracycline resistant bacteria were mainly dominated in adult fishes by the genus Flavobacterium (23\%) and Enterobacteriace(41\%). Selected strains exhibited high levels of oxytetracycline resistance with minimum inhibitory concentrations (MICs) ranging from 50 to $600 \mu \mathrm{g} / \mathrm{ml}$. This study shows the presence of an important population of oxytetracycline-resistant bacteria in the microflora of Indian carp aquaculture farms. Therefore the environment of these farms might play important roles as reservoirs of bacteria carrying genetic determinants for high level tetracycline resistance, prompting an important risk to public health.
\end{abstract}

Keywords: Oxytetracycline; Bacteria; Antimicrobial resistance; Aquaculture system; Minimum inhibitory concentration

\section{Introduction}

Antimicrobial agents have been widely used in aquaculture worldwide to treat infections caused by a variety of bacterial pathogens of fish. Use of antimicrobial agents in aquaculture also selects for antimicrobial resistance among bacteria that are not fish pathogens. Several studies have assessed the impact of use of antimicrobial agents in aquaculture on the bacteria in the sediment and within fish in the local environment. In the field of aquaculture, the antimicrobial agents are used mainly as a growth promoter as well as therapeutic. The use of antimicrobial drugs for treatment and control the disease problems due to intensive fish farming has been increased significantly. During medical treatment of bacterial fish diseases antimicrobial agents are released into the surrounding water. There are large volumes of different fish pathogens around the world (Rahim et al, 1989; Richards et al, 1991; Tsoumas et al, 1989; Hjeltnes et al, 1987). Only a small fraction of the aquatic bacteria are pathogenic but development and spread of antibiotic resistance in the bacterial population may result into serious environmental consequences. Thus the impact of these substances on the micro flora (aquatic) and the resistance patterns of bacterial fish pathogens often reflect an intensive use of antimicrobial substances.

In Chile, a high frequency of antibiotic resistant bacteria has been reported in polluted and unpolluted freshwater (Miranda and Castillo,
1998). In other countries like Denmark, USA etc. oxytetracycline is the most frequently used antibacterial in aquaculture because of its broad spectrum of activity. This antibiotic binds to the $30 \mathrm{~S}$ subunit of the microbial $70 \mathrm{~S}$ ribosome inhibiting protein synthesis by blocking the attachment of aminoacyl-tRNA units. But the intensive use of oxytetracycline in fish farming has been encountered with increased frequency of oxytetracycline resistant microorganisms (Samuelsen et al, 1992; Hansen et al 1993; De Paola, 1995) Antimicrobial-resistant bacteria which result from use of antimicrobial agents in aquaculture can transfer these resistance determinants to other bacteria. Many antibiotic resistance determinants in fish pathogens are frequently carried on transferable $R$ plasmids (Wattanabe et al, 1977). Horizontal spread of plasmids from fish pathogens may therefore transfer resistance genes to other bacteria including those that are pathogenic to humans Horizontal transfer of resistance genes on plasmids has been demonstrated between bacteria in the water of fish ponds (Aoki,1997) and in marine sediments(Stewart and Sinigalliano,1990). In the unorganized sector of India also there has been indiscriminate use of this antibiotic to overcome any disease problems as well as growth promoter. Therefore the prophylactic use of oxytetracycline in carp aquaculture increases the risk of transfer of antibiotic resistance to human pathogens associated with fish 
consumptions. At present no studies on antibiotic resistant bacteria in carp aquaculture farming have been performed despite the importance of this industry in India. Therefore it was considered important to evaluate the possibility of oxytetracycline resistant bacteria in Indian major carps aquaculture environment. The aim of the present study was to determine the prevalence and persistence of antimicrobial resistance in a typical Indian freshwater aquaculture with numerous carp aquaculture farms and therefore focused on the study of total resistant bacterial flora and the specific resistance patterns of all isolates in order to register local changes and differences among the fish farms.

\section{Materials and methods \\ 2.1 Sampling sites}

The three freshwater Indian major carps aquaculture farms from which carp fishes (Rohu, Labio rohita; catla, Catla catla; Nayan, C. mrigal) were sampled, was located in and around Lucknow city, U.P. Farm 1 was located in the Lucknow and the other two farms i.e. farm 2 and farm 3 were located $80 \mathrm{~km}$ west to Lucknow city and $200 \mathrm{~km}$ east to Lucknow city respectively. The ponds of each farm were receiving water mainly from tube well water supply. Polyculture of carps was practiced regularly in these farms. Each farm had a surface area of about 4 hectares. These farms fulfill the major seed requirement of the state. Each of these farms has target of over 5 crores of seeds in a breeding season. The sampled farms were not exposed to antibacterial therapy for more than six months before the sampling period. Adult fishes of major carps were also sampled from different market places of the Lucknow. All these samplings were done between July to November.

\subsection{Sampling}

Water samples from different fish farm's influents, spawn/fry culture were considered and collected aseptically in sterile $500 \mathrm{ml}$ wide mouth glass bottles (schott duran, Germany). Samples of different life stages of fish namely spawn, fry, fingerlings and unmedicated fish food pellet samples were collected in sterile plastic bags from each farm. Fish samples were placed on ice immediately transported to the laboratory and maintained in the tanks of above 50 liters capacity while feed samples were stored at $4{ }^{\circ} \mathrm{C}$ in refrigerator and processed within 24 hours after collection. Adult fishes (weight $250 \mathrm{~g}$ each) were sampled from different market places in Lucknow. The fishes were placed individually in plastic bags covered with ice and transported to the laboratory.

\subsection{Processing of samples}

Water samples from the influents and rearing ponds which were sampled in sterile bottles and serially diluted in sterile normal saline $(0.85$ $\% \mathrm{NaCl}$ ). Fish samples (fingerlings and adult) were externally washed with sterilized distilled water to minimize contamination with skin bacteria. Spawn, fry samples and palletized feed were placed on sterile Petri dishes, weighed and grinded by hand using a sterile glass digester or by homogenizer. Homogenates of these samples were serially diluted in sterile normal saline $(0.85 \% \mathrm{NaCl})$ solution. Aliquots $(100 \mu \mathrm{l})$ of appropriate dilutions of homogenates of the palletized feed, fish and water samples were spreaded on the nutrient agar (NA) medium and nutrient agar supplemented with oxytetracycline (ONA) plates using spread plate techniques in duplicate and incubated at $37^{\circ} \mathrm{C}$ for $24-48$ hours.

\subsection{Nutrient agar containing oxytetracycline (ONA)}

ONA plates were prepared by supplementing the oxytetracycline in the nutrient agar medium. Oxytetracycline was obtained from Hi-media and stored in the dark at $4^{\circ} \mathrm{C}$. Filter sterilized oxytetracycline stock solutions were prepared by the addition of $1 \mathrm{~N} \mathrm{NaOH}$ (Hi media) drop wise to a drug suspension in distilled water until the compound was dissolved. Then it was adjusted to $\mathrm{pH} 7.0$ with $0.1 \mathrm{M} \mathrm{HCl}$ and filter sterilized $(0.22 \mu \mathrm{m})$ before using into the nutrient agar solution. The concentration of oxytetracycline in nutrient agar solution was maintained at $50 \mu \mathrm{g} / \mathrm{ml}$ for determining the level of resistant bacteria.

\subsection{Isolation and identification}

Nutrient agar (NA) was used for determination of total viable count of bacteria, however for the resistant bacteria nutrient agar supplemented with oxytetracycline $(\mathrm{ONA})(50 \mu \mathrm{g} / \mathrm{ml})$ was used. From each plate colonies showing difference in morphology were randomly selected and transferred to a fresh plate. Streaking and restreaking were continued until pure culture was obtained. Gram's staining, $\mathrm{KOH}$ test, motility were routinely performed. In addition an array of biochemical tests like catalase, cytochrome oxidase, gelatin, indole production, voges proskaur, $\mathrm{H}_{2} \mathrm{~S}$ production, arginine, lysine and ornithin decarboxylases, methyl red, simmon citrate utilization, growth in triple sugar iron, aesculine hydrolysis, urease production, gas and acid from glucose (Hugh and Leifson medium) and acid from carbohydrates (Mannitol, Mannose, Trehlose, Sucrose, Dulcitol, Arabinose, Rhaminose, Lactose, Inositol, Melibiose etc.) were performed to identify isolates at least upto genus levels as per Cowan's steel manual, Austin and Austin manual and according to the instructions of the manufacturers. Tests were incubated at $37^{\circ} \mathrm{C}$ and results were recorded after 24-48 hours but only results after 48 hours of incubation were considered.

\subsection{Bacterial strains}

Oxytetracycline resistance was studied on ONA plates for all the samples. Sixty-two gram 
negative bacilli were picked at random from the ONA plates to represent oxytetracycline resistant bacterial community from each Indian major carp farm. Among the 62, a total of 27 were recovered from farm I, 13 were recovered from farm II, 10 were recovered from farm III, 12 from adult fishes (Table 3 ). Isolates were purified onto nutrient agar (Hi-media) and maintained at $-80^{\circ} \mathrm{C}$ in nutrient broth containing $15 \%$ glycerol. When needed, frozen organism were recovered by streaking onto NA plates containing oxytetracycline $(50 \mu \mathrm{g} / \mathrm{ml})$ which were incubated at $37^{\circ} \mathrm{C}$ for $24-48$ hours.

\subsection{Minimum inhibitory concentration (MIC's)}

Minimum inhibitory concentration (MIC's) was defined as the lowest concentration of oxytetracycline producing absence of growth after 48 hours. MICs of oxytetracycline against all strains were determined by tube dilution method. Dilution pattern of oxytetracycline were added to obtain final concentration ranging from $50 \mu \mathrm{g} / \mathrm{ml}$ to $400 \mu \mathrm{g} / \mathrm{ml}$. Duplicate tubes were inoculated and incubated for 24 hours at $37^{\circ} \mathrm{C}$. MICs of resistant strains were recorded as the lowest concentration of the antibiotic inhibiting the growth of culture.

\subsection{Antibiotic sensitivity test of oxytetracycline resistant isolates}

The twelve isolates of different genus representing the whole isolates were tested by disc diffusion techniques for sensitivity to seven antimicrobial agents. Commercially available standard antibiotic discs were obtained from $\mathrm{Hi}$ media, Mumbai. The abbreviations and strength of the antibiotics are given in the brackets. The antibiotic discs used were Chloramphenicol(C-mcg), Ciprofloxacin (Cf $\mathrm{mcg}$ ), CoTrimaxazole (Co - mcg), Gentamicin $(\mathrm{G}-\mathrm{mcg})$, Nitrofurazone $(\mathrm{Nr}-\mathrm{mcg})$, Novobiocin ( $\mathrm{Nv}-\mathrm{mcg})$, Oxytetracycline (O $\mathrm{mcg}$ ). Mueller Hinton Agar was prepared and poured into Petri dishes. Seven discs of different antibiotics were placed on each of two Petri plates per isolates immediately after inoculation and incubated at $30^{\circ} \mathrm{C}$. Plates were read after 48 hours and the diameter of the zone of inhibition (including disc diameter) was measured in millimeter with calipers. The bacterial cultures were described as sensitive, intermediate sensitive or resistant to each antibiotic according to the antibiotic manufacturers table of recommendations.

\section{Results}

\subsection{Water and feed bacteriology}

The overall bacterial counts in pond water for all the three farms on NA plates ranged between $2.7 \times 10^{3}$ and $2.08 \times 10^{5}$ bacteria per $\mathrm{ml}$ (cfu/ml) while for two feed samples were $3.55 \times 10^{6} \mathrm{cfu} / \mathrm{gm}$ and $4.78 \times 10^{5} \mathrm{cfu} / \mathrm{gm}$ for farm I and farm II respectively. (Table 1)

\subsection{Fish samples:}

The total bacterial concentration in fish samples were ranged in spawn $\left(1.86 \times 10^{7}\right.$ to $\left.3.5 \times 10^{8} \mathrm{cfu} / \mathrm{gm}\right)$, fry $\left(1.95 \times 10^{7}\right.$ to $1.24 \times 10^{8}$ $\mathrm{cfu} / \mathrm{gm})$ and fingerling $\left(1.64 \times 10^{7}\right.$ to $1.1 \times 10^{8}$ $\mathrm{cfu} / \mathrm{gm})$. The total bacterial load was higher in all the life stages of fish from farm III as compared to the other two farms. The total plate count of fish muscle tissue of adult fishes ranged from $1.04 \times 10^{6}$ to $2.4 \times 10^{8} \mathrm{cfu} / \mathrm{gm}$. (Table 2)

\subsection{Oxytetracycline resistance in bacterial isolate:}

The oxytetracycline resistance was studied on ONA plates for all the samples and was detected as follows - Pond water $\left(1.25 \times 10^{1}\right.$ to $\left.1.4 \times 10^{3} \mathrm{cfu} / \mathrm{ml}\right)$, Feed $\left(2.4 \times 10^{3}\right.$ to $1.6 \times 10^{4}$ cfu/gm), Spawn $\left(2.75 \times 10^{3}\right.$ to $\left.7.8 \times 10^{4} \mathrm{cfu} / \mathrm{gm}\right)$, Fry $\left(4 \times 10^{2}\right.$ to $\left.3.87 \times 10^{4} \quad \mathrm{cfu} / \mathrm{gm}\right)$, Fingerling $\left(1.4 \times 10^{3}\right.$ to $\left.2.5 \times 10^{5} \mathrm{cfu} / \mathrm{gm}\right)$ and Adult fish $\left(4 \times 10^{3}\right.$ to $\left.6.4 \times 10^{4} \mathrm{cfu} / \mathrm{gm}\right)$.(Table 1 and 2$)$. Sixty two isolates were resistant to oxytetracycline (Table 4). The bacterial profile of the oxytetracycline resistant isolates comprised of Flavobacterium (21\%), Alcaligenes (14.5\%), Aeromonas (11\%), Pseudomonas (10\%) and Enterobacteriace $(19 \%)$. Among the Enterobacteriace, Escherichia, Serratia, Citrobacter, Enterobacter, Shigella and Proteus were recovered. 12 isolates of oxytetracycline resistant bacteria isolated from adult fishes were mainly dominated by the genus Flavobacterium (23\%) and Enterobacteriace(41\%) (Table 4)

3.4 Oxytetracycline resistant bacterial profile of different life stages of fish

3.4.1 Spawn: - From all the three farms, 14 bacterial isolates were recovered from spawn samples which were resistant to oxytetracycline. Among these, the relative frequencies of genus were as follows. Alcaligenes (28\%), Vibrio, Pseudomonas and Enterobacteriace(14\%) each. (Table 4 and 6)

3.4.2 Fry: - From fry samples, 13 bacterial isolate were recovered resistant to oxytetracycline. The bacterial profile of 13 resistant isolates were as follows: - Alcaligenes (23\%), Flavobacterium (23\%), Aeromonas (23\%), Vibrio, Pseudomonas, Enterobacteriace $(13 \%)$ each. (Table 4 and 6$)$

3.4.3 Fingerlings: - From fingerlings samples from all the three farms, 10 resistant bacterial isolates were recovered. Among 10 oxytetracycline resistant isolates, the relative frequencies of genus were as follows: Flavobacterium (30\%), Aeromonas(20\%), Pseudomonas(20\%), Alcaligenes(10\%), Vibrio (10\%), Moraxella (10\%). (Table 4 and 6)

3.4.4 Adult fishes: - From adult fish samples from domestic market of Lucknow, 12 oxytetracycline resistant isolates were recovered. Among the 12 resistant isolates the relative frequencies of genus are as follows: - 
Enterobacteriace (41\%), Flavobacterium(23\%) and others (25\%). (Table 4 and 7 )

\subsection{Oxytetracycline resistant bacteria profile of feed and water samples}

The six oxytetracycline resistant bacterial isolates were recovered from the feed samples collected from farms. The relative frequencies of some genus were as follows: Enterobacteriacea (46\%), Flavobacterium $(16 \%)$ and Alcaligenes (16\%). Seven oxytetracycline resistant isolates were recovered from water samples of which the relative frequencies of some genus were as follows: - Acinetobacter (28\%), Moraxella $(28 \%)$ and others (44\%). (Table 4)

\subsection{Resistant bacterial profile of individual fish farms}

3.6.1 Farm I: - Among all the isolates recovered from the 14 samples collected from farm I, 27 bacterial isolates were resistant to oxytetracycline (Table 8 and 6). The total plate count on ONA plates for different samples were as follows - Pond water $\left(1.25 \times 10^{\top} \mathrm{cfu} / \mathrm{ml}\right)$, Feed $\left(1.6 \times 10^{4} \mathrm{cfu} / \mathrm{gm}\right)$, Spawn $\left(7.8 \times 10^{4}\right.$ cfu/gm), Fry $\left(3.87 \times 10^{4} \mathrm{cfu} / \mathrm{gm}\right)$ and Fingerling $\left(\begin{array}{ll}2.5 \times 10^{5} & \mathrm{cfu} / \mathrm{gm}) .(\text { Table } 1\end{array}\right)$. The relative frequency of some genus among the 27 oxytetracycline resistant isolates were as follows - Alcaligenes (22\%), Pseudomonas (15\%), Vibrio(4\%), Escherichia(4\%), Providencia (2\%), Moraxella (11\%), Staphylococcus (4\%), Bacillus (4\%) and other unidentified (4\%). (Table 4 and Table 6 )

3.6.2 Farm II: - Thirteen bacterial isolates were found resistant to oxytetracycline among all the isolates recovered from the 8 samples collected from farm II, (Table 8 and Table 6). The total plate count on ONA plates for different samples were as follows - Pond water $\left(1.4 \times 10^{3} \mathrm{cfu} / \mathrm{ml}\right)$, feed $\left(2.4 \times 10^{3} \mathrm{cfu} / \mathrm{gm}\right)$, Spawn $\left(5.4 \times 10^{3} \mathrm{cfu} / \mathrm{gm}\right)$, Fry $\left(4 \times 10^{2} \mathrm{cfu} / \mathrm{gm}\right)$ fingerling $\left(3.8 \times 10^{3} \mathrm{cfu} / \mathrm{gm}\right)$.(Table 1). Out of 13 oxytetracycline resistant isolates the dominant frequencies of some genus were as follows: Vibrio $15 \%)$

Enterobacter(15\%), Proteus(15\%), Aeromonas(8\%), Citrobacter (8\%), Alcaligenes(8\%), (Flavobacterium (7\%) and Pseudomonas(7\%). (Table 4 and Table 6).

3.6.3 Farm III: - Ten bacterial isolates were found resistant to oxytetracycline from all the isolates recovered from the 7 samples collected from farm III (Table 8 and 6). The total plate count on ONA plates for different samples were as follows: - Pond water $\left(2.9 \times 10^{2}\right.$ $\mathrm{cfu} / \mathrm{ml})$, Feed( $\left.2.3 \times 10^{4} \mathrm{cfu} / \mathrm{gm}\right)$, Spawn $\left(2.75 \times 10^{3}\right.$ cfu/gm), Fry $\left(2.4 \times 10^{3}\right.$ cfu/gm), and Fingerling $\left(1.4 \times 10^{3} \mathrm{cfu} / \mathrm{gm}\right)$ (Table 1).The frequencies of some genus were as follows Flavobacterium(50\%), Alcaligenes(20\%), Aeromonas(20\%), Vibrio(10\%). (Table 4)

3.7 Antibiotic sensitivity pattern of oxytetracycline resistant isolates
The antibiotic sensitivity of 12 isolates representing each gram -ve genus was studied by disk diffusion technique using 7 antibiotics. Out of these 12 isolates, 10 isolates were recovered from ONA plates and two isolates of Aeromonas and Klebsiella were isolated from NA plates. All the 12 isolates were mostly sensitive to all the tested antibiotics except Nitrofurazone and oxytetracycline. The detail antibiotic sensitivity pattern of oxytetracycline resistant isolates is given in Table 10 .

\section{Discussion}

The apparent increases of the occurrence of antibiotic resistance among bacteria from various fish production farms and its possible implications for public health have in many countries lead to an intensified surveillance of bacterial resistance. In the field of aquaculture both the therapeutic and environmental problems have been addressed, as antimicrobial agents are released into the surrounding water during medical treatment of bacterial fish diseases (Aoki, T, 1992; Bjorkluna, H. 1991). The impact of these substances on the resident micro flora is difficult to assess because of the complexity of aquatic environment while the resistance patterns of the bacterial fish pathogens often reflect an intensive use of antimicrobial substances. The total viable concentration of bacteria on nutrient agar plate of inlet water was nil for all the three farms. This was due to the fact that inlet water being used in farms for hatching and rearing of fish was mainly ground water which was also being used for human consumption. This predicts that the inlet water being used as safe, potable and the level of bacterial pathogens harmful to fish was insignificant. The total plate count (TPC) of inlet water lower than that of both pond water as well as from spawn, fry and fingerlings. This observation has been reported by earlier studies in Penaeus indicus (Sahul Hameed, 1993) and Microbrachium rosenbergii (Phatarpekar et al, 2002). The TPC of the pond water in the present study was $2.08 \times 10^{5} \mathrm{cfu} / \mathrm{ml}$ to $2.7 \times 10^{3} \mathrm{cfu} / \mathrm{ml}$ were lower than those reported previously by phatarpekar et al, 2002 $\left(1.1 \times 10^{4}\right.$ to $\left.9.8 \times 10^{6} \mathrm{cfu} / \mathrm{ml}\right)$. This may be due to intensive culture practices being adopted for the farming of the shrimps as well as freshwater prawns. Earlier studies suggested that there is a positive correlation between bacterial counts of pond water and the level of total suspended solids (Anderson et al.1989). Thus it appears that high bacterial population can be a result of chemical parameters such as intensive feeding and overstocking. So it is suggested that if the physical-chemical parameters of water are maintained within normal ranges, optimum stocking and feeding is done, it can result in lower bacterial load in the rearing ponds. In our study we found less bacterial load of pond in all the three farms of Indian Major Carps (IMC's) which could be due to good management practices. The total plate 
count for two feed samples was $3.55 \times 10^{6}$ and $4.78 \times 10^{5} \mathrm{cfu} / \mathrm{ml}$ for farm I and farm II respectively. So feed can be one of the sources for higher bacterial load in the pond water. The high frequency of oxytetracycline resistant bacteria observed in feed sample in farm II (46\%) which strongly supports the hypothesis that the resistant micro flora introduced in the feed might be one of the most important sources of the elevated frequency of resistance in these systems. The bacterial species identified in this study are similar to those isolated by Spanggard et al (1993) from Danish freshwater rainbow trout farms exhibiting resistance to oxytetracycline. These isolates were mainly identified as Vibrionaceae, Enterobacteriacea, Acinetobater Pseudomonas spp, Moraxella spp. and Aeromonas. The incidence of oxytetracycline resistant strains in pond water of farm I could be explained by the acquisition of resistant gene which protects from microbicidal effects of antibiotics that are produced by bacteria and substances in nature (Kadarvy et al 2000). These resistance genes could be maintained within the population protecting the bacteria from antibiotics produced by other members of micro flora. The frequencies of oxytetracycline resistant bacteria in feed sample are high when compared to those reported in previous studies (Miranda and Zemelman, 2002). The proportions of oxytetracycline resistance in fry found in this study are high in farm III (55\%) when compared to other two farms i.e. farm I $(22 \%)$ and farm II (15\%). Frequencies of oxytetracycline bacteria in IMC's fingerling are less when compared to those reported in previous studies (Miranda and Zemelman 2002). Therefore the proportions of oxytetracycline resistance found in this study are much less than those observed from fish farming bacteria associated with four Danish rainbow trout fish farms (Schemidt et al 2001). This results that the chemotherapy in developed countries are much higher than the developing countries. In this country there is less degree of chemotherapy but heavy over stocking of fish causes the pathogencity in fresh water aquaculture system. The range of minimum inhibitory concentration (MIC's) of oxytetracycline against oxytetracycline resistant strains is shown in figures 1-5. High levels of oxytetracycline resistance were observed for the selected bacterial strains with MIC values ranging from 60 to $600 \mu \mathrm{g} / \mathrm{ml}$. The lowest MIC's were observed against resistant strains recovered from farm II, where more than $85 \%$ of these strains exhibited $\leq 100 \mu \mathrm{g} / \mathrm{ml}$ values. On the contrary, the highest MIC's were found against strains from farm III, showing $600 \mu \mathrm{g} / \mathrm{ml}$ values in approximately $14 \%$ of strains. In Farm I, MIC of oxytetracycline against the oxytetracycline resistant strains ranges 60 to $600 \mu \mathrm{g} / \mathrm{ml}$. 92\% strains were found sensitive to $160 \mu \mathrm{g} / \mathrm{ml}$ and $7.6 \%$ found sensitive to $600 \mu \mathrm{g} / \mathrm{ml}$. In Farm II, the MIC ranges from 60 to $140 \mu \mathrm{g} / \mathrm{ml}$. About $88 \%$ strains were found sensitive to $100 \mu \mathrm{g} / \mathrm{ml}$ and $11 \%$ strains were found sensitive to $140 \mu \mathrm{g} / \mathrm{ml}$. Among all the three farms, farm II has lowest MIC against resistant strains. Similarly for farm III, the MIC values range from 60 to $600 \mu \mathrm{g} / \mathrm{ml}$. The highest $\%$ frequency of strains i.e. $70 \%$ exhibited MIC value between $100-300 \mu \mathrm{g} / \mathrm{ml}$ and $14.2 \%$ of strains exhibit MIC value between 300- 600 $\mu \mathrm{g} / \mathrm{ml}$. Among adult fishes, $50 \%$ of strains were found to exhibit $\leq 300 \mu \mathrm{g} / \mathrm{ml}$ and around $50 \%$ of strains exhibited MIC value between $300-600$ $\mu \mathrm{g} / \mathrm{ml}$. No correlation between MIC values and bacterial species was observed. Tetracycline might be considered as an important therapy since oxytetracycline is used to treat a variety of diseases including enteric red mouth disease caused by Yersinia ruckere and flavobacteriosis disease by Flavobacterium psychrophilum and F. columnare. In addition this antibiotic is currently used as a preventive treatment. Since oxytetracycline was not currently used during sampling period. In this study the high frequency of resistant bacteria found in the sample as well as the high resistance levels of the microorganisms might be consequences of previous use of this compound in the fish farms having persisted selective effect during the period in which no antibiotic has been used. Factors responsible for the occurrence of antibiotic resistance in absence of antibiotic use are still unclear. Some reports indicate that relatively high levels of nutrients may give rise to increase in the frequency of resistant bacteria in aquatic environment in the absence of antibiotic use (Husevag et al 1991; Mc Phearson et al 1991; Vaughan et al 1996). These bacteria appear to be tolerant to antibiotic as a consequence of mutation producing alterations in outer membrane proteins (Barnes et al 1990; Hansen et al 1993; Smith et al 1997; Chopra and Roberts, 2001). Oxytetracycline which is a very commonly used antibiotic approved by the U.S. food and drug administration (FDA) as feed additives against bacterial infections of cultured fish and has been shown to enhance the production of plasmid mediated resistance in aquatic bacteria (Shotts et al 1976) resulting in increasing the frequency of new oxytetracycline resistant isolates (William et al 1992). The results obtained in this study suggest that high number of resistant bacteria exist in freshwater carps farming environment which indicates the possibility of transfer of resistance determinants into fish pathogenic bacteria (Sandaa et al 1992) and returning of resistant enteric bacteria into fish consumers might occur (Midtvedt and Lingaas, 1992). Therefore the use of oxytetracycline should be done judiciously in aquaculture practices and further molecular investigations are needed in order to evaluate the presence of genetically mobile antibiotic resistance genes in humans and animal food chain (Levy, 1969; Young, 1993; Sorum, 1998). This result also indicates that the necessary steps should be taken towards stabilizing policies (Gould, 1999) in order to 
reduce current levels of resistance in freshwater fish industry. The presence of high numbers of oxytetracycline resistant bacteria in freshwater fish farms has public health implications and emphasizes the need for further studies concerning the gene encoding resistance in different bacterial species resistance in different bacterial species as well as on the possibility of returning of resistance genes to human population through fish consumption. The antibiogram study reveal that all the isolates were resistant to Oxytetracycline, Nitrofurazone and Novobiocin but sensitive to Chloramphenicol (C), Ciprofloxacin (cf) and Gentamycin (g). With respect to other antibiotics the isolates exhibited varying degrees of sensitivity or resistance. The antibiotics like Ciprofloxacin and Chloramphenicol revealed extreme degree of zone of inhibition for all the representative bacterial cultures. Therefore the choice of these antibiotics should draw attention for controlling diseases caused by these bacterial pathogens. Chloramphenicol although known to cause growth suppression has a wide spectrum of antimicrobial activity. It exerts marked therapeutic effects against sensitive organisms (Sande and Madell, 1985). Nitrofurazone showed resistance to Aeromonas species conforming the observations of Sahoo and Mukherjii (1970). Based on the data from this study, the resistant and intermediate sensitive/resistant antibiotics would be poor choices for consideration as antibiotic in freshwater aquaculture systems involving these pathogens. The differences between in vitro and in vivo activities of antibiotics are often very dramatic because demonstrated efficacy in vitro may not be expressed during in vivo clinical or field trials. The sensitive antibiotics should be useful in controlling common gram negative bacterial diseases in aquaculture but require further testing for their in vivo efficacy.

\section{Conclusions}

This study demonstrate that Indian freshwater carps farms exhibit significant frequencies of bacteria with low and high level resistance to oxytetracycline mainly in pelletized feed. The high percentage of oxytetracycline-resistant bacteria was also observed in adult fishes. Therefore carp culture farms may play an important role as reservoirs of antibiotic resistant bacteria and thereby increase a public health hazard. Further studies are necessary to determine the potential public health significance of important numbers of resistant bacteria in Indian freshwater carps farming to elucidate the possibility of transmitting multiresistant bacteria to farm personnel or human consumers.

\section{Acknowledgements}

This study was supported in part by the U.P. Technical University and National Bureau of Fish Genetic Resources. We would like to thank Mr. D.K. Chaudhary, Senior research fellow, National Bureau of fish genetic resources, Lucknow, for his comments and suggestions which helped to improve this work.

\section{References}

[1] Anderson I.G., Shamsudin M.N. and Nash G. (1989) Aquaculture, 81: 213223.

[2] Aoki T. (1997) Resistance plasmids and the risk of transfer. In: Bernoth EM, ed. Furunculosis: multidisciplinary fish disease research. London, Academic Press: 433-440.

[3] Aoki T. (1992) Present and future problems concerning the development of resistance in aquaculture. In Michel, C., Alderman, and D.J. (Eds.), Chemotherapy in aquaculture: From theory to Reality. Office International des Epizooties, Paris. pp. 254-262.

[4] Barnes A.C., Lewin C.S., Hastings T.S., Amyes S.G.B., (1990) FEMS. Microbial. Lett. 22, 337-340.

[5] Bjorklund H. (1991) oxytetracycline and oxolinic acid as antimicrobials in aquaculture analysis, pharmacokinetics and environmental impact. Thesis. Abo university, Finland.

[6] Bjorklund H., Raberg E.M.I., Bylund G. (1991) Aquaculture. 97, 85-96.

[7] Chopra I., Roberts M. (2001) Microbiol. Mol. Rev. 65, 232-260.

[8] De Paola A. (1995) J. Aquat. Anim. health 7, 155-160.

[9] Gould I.M. (1999) J. antimicrob Chemother. 43, 459-465.

[10] Hansen P.K., Lunestad B.T., Samuelsen O.B. (1993) Can.J.Microbiol. 39, 1307-1312.

[11] Hjeltnes B., Anderson K., Egidius E. (1987) Bull. Eur. Assoc. Fish Pathol. 7,85 .

[12] Husevag B., Lunestad B.T., Johannessen P.J., Enger O., Samuelsen O.B. (1991) J.Fish Dis.14, 631-640.

[13] Kadavy D.R., Hornby J.M., Haverkost T., Nickerson K.W.(2000) Appl. Environ Microbiol. 66, 4615-4619.

[14] Levy S.B. (1989) J. Antimicrob. Chemother. 24, 1-7.

[15] Mc Phearson R.M. Depaola A., Zywno S.R., Motes Jr. M.L., Guarino A.M., (1991) Aquaculture 99, 203-211.

[16] Midtvedt T., Lingaas E. (1992) Putative public health risks of antibiotic resistance development in aquatic bacteria. In: Michel., C, Alderman, D.J.(Eds.), Chemotherapy in aquaculture in aquaculture: From theory to reality, office international des epizooties, paris, pp. 302-314.

[17] Miranda C.D., Castillo G. (1998) Sci. Total environ. 224, 167-176.

[18] Miranda C.D., Zemelman R. (2002) Aquaculture, 212, 31-47. 
[19] Rahim Z., Sanyal S.C., Aziz K.M.S., Huq. M.I., Chawdhary A.A. (1984) Appl. Environ. Microbiol. 48, 865-867.

[20] Richards R.H., Inglis V., Frerichs G.N., Miller S.D. (1991) Variation in antibiotic resistance patterns of Aeromonas salmonicida isolated from Atlantic Salmon Salar L. in Scotland. Working papers from the conference: Problems of chemotherapy from Theory to Reality, Paris, 12-15 March, 1991.

[21] Samuelsen O.B., Torsvik V., Ervik A. (1992) Sci. Total Environ. 114, 25-36.

[22] Sandaa R.A., Torsvik V.L., Goksoyr J. (1992) Can. J. Microbiol. 38, 10611065.

[23] Sande M.A. and Mandell G.L. (1985) Antimicrobial agents: Tetracyclines and chloramphenicol: In: The pharmacological basis of Therapeutics. A.G. Gilman, L.S. Goodman, T.W.Roll and F.Murad (Eds.), Mac Millan Publishing Co. New York, P. 1170-1198.

[24] Schimdt A.S., Bruun M.S., Dalsgaard I., Larsen J.L. (2001) Appl. Environ. Microbiol. 67, 5675-5862.

[25] Shotts E.B., Vander work V.L. and Campbell L.M. (1976) J. Fish. Res. Bd. Can., 33; 736-740.

[26] Smith P., Brogan L., Brophy N., Frawley M., Collins D. (1997) Abstr. VIIlth Eur. Assoc. Fish Pathol. (Edinburgh), P. 117.

[27] Sorum H. (1998) APMIS, 106, 74-76.

[28] Spanggaard B., Jorgensen F., Gram L., Huss H.H. (1993) Aquaculture, 115, 195-207.

[29] Stewart G.J, Sinigalliano C.D. (1990) Applied and Environmental Microbiology 56:1818-1824.

[30] Tsoumas A. Alderman D.J., Rodgers C.J. (1989) J. Fish Dis. 12, 493-507.

[31] Vaughan S., Coyne R., Smith P. (1996) Aquaculture 139, 47-54.

[32] Watanabe T.T., Aoki Y., Ogata Y., Egusa, S. (1977) Annuals of the New York Academy of Science. 182:383-410.

[33] Williams R.R., Bell T.A and Lightner D.V. (1992) J. Aqua. Anim. Health., 4: 262270.

[34] Young H.K. (1993) J. Antimicrob. Chemother. 31, 627-635. 
Table 1: Total, Ampicillin and Oxytetracycline - resistant viable bacterial concentrations from Indian major carp's farms

\begin{tabular}{|c|c|c|c|c|c|c|c|c|c|c|c|c|c|c|c|}
\hline \multirow{4}{*}{ 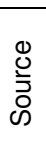 } & \multicolumn{15}{|c|}{ VIABLE COUNT (CFU/mI OR CFU/gm) } \\
\hline & \multicolumn{5}{|c|}{ FARM I } & \multicolumn{5}{|c|}{ FARM II } & \multicolumn{5}{|c|}{ FARM III } \\
\hline & \multirow[b]{2}{*}{ NA } & \multicolumn{2}{|c|}{ SAA } & \multicolumn{2}{|c|}{ ONA } & \multirow[b]{2}{*}{ NA } & \multicolumn{2}{|c|}{ SAA } & \multicolumn{2}{|c|}{ ONA } & \multirow[b]{2}{*}{ NA } & \multicolumn{2}{|c|}{ SAA } & \multicolumn{2}{|c|}{ ONA } \\
\hline & & TC & $\%$ & TC & $\%$ & & TC & $\%$ & TC & $\%$ & & TC & $\%$ & TC & $\%$ \\
\hline $\begin{array}{l}\mathrm{P} \\
\mathrm{W}\end{array}$ & $2.7 \times 10^{3}$ & $\begin{array}{l}1.27 \times 1 \\
0^{3}\end{array}$ & 47 & $\begin{array}{l}1.25 x \\
10^{1}\end{array}$ & $\begin{array}{c}0 . \\
46\end{array}$ & $\begin{array}{r}2.09 x \\
10^{4}\end{array}$ & $\begin{array}{r}9.5 x \\
10^{3}\end{array}$ & $\begin{array}{c}45 . \\
4\end{array}$ & $\begin{array}{r}1.4 \mathrm{x} \\
10^{3}\end{array}$ & $\begin{array}{c}0 . \\
06\end{array}$ & $\begin{array}{r}2.08 x \\
10^{5}\end{array}$ & $\begin{array}{r}1.04 \mathrm{x} \\
10^{5}\end{array}$ & 50 & $2.9 \times 10$ & 0.13 \\
\hline $\begin{array}{l}F \\
E\end{array}$ & $\begin{array}{r}3.55 \times 1 \\
0^{6}\end{array}$ & $\begin{array}{l}2.51 \times 1 \\
0^{6}\end{array}$ & $\begin{array}{l}70 \\
.7\end{array}$ & $\begin{array}{l}1.6 \times 1 \\
0^{4}\end{array}$ & $\begin{array}{c}0 . \\
63\end{array}$ & $\begin{array}{r}4.78 x \\
10^{5}\end{array}$ & $\begin{array}{r}1.5 x \\
10^{4}\end{array}$ & $\begin{array}{c}3.1 \\
3\end{array}$ & $\begin{array}{r}2.4 x \\
10^{3}\end{array}$ & $\begin{array}{c}0 . \\
50\end{array}$ & N.D. & N.D. & $\begin{array}{l}\text { N. } \\
\text { D. }\end{array}$ & N.D. & N.D. \\
\hline $\begin{array}{l}S \\
P\end{array}$ & $\begin{array}{r}8.5 \times 1 \\
0^{7}\end{array}$ & $\begin{array}{l}2.11 \times 1 \\
0^{7}\end{array}$ & $\begin{array}{l}28 \\
.8\end{array}$ & $\begin{array}{l}7.8 \times 1 \\
0^{4}\end{array}$ & $\begin{array}{c}0 . \\
09\end{array}$ & $\begin{array}{r}1.86 x \\
10^{7}\end{array}$ & $\begin{array}{r}4.8 x \\
10^{6}\end{array}$ & $\begin{array}{c}25 . \\
8\end{array}$ & $\begin{array}{r}5.4 x \\
10^{3}\end{array}$ & $\begin{array}{c}0 . \\
03\end{array}$ & $\begin{array}{r}3.5 x \\
10^{8}\end{array}$ & $\begin{array}{r}2.1 x \\
10^{7}\end{array}$ & 6 & $\begin{array}{r}2.75 \times 1 \\
0^{3}\end{array}$ & $\begin{array}{c}0.00 \\
7\end{array}$ \\
\hline $\begin{array}{l}F \\
R\end{array}$ & $\begin{array}{r}1.95 x \\
10^{7}\end{array}$ & $\frac{1.7 \times 10}{7}$ & .17 & $\begin{array}{l}3.87 x \\
10^{4}\end{array}$ & $\begin{array}{c}0 . \\
19\end{array}$ & $\begin{array}{r}2.2 x \\
10^{7}\end{array}$ & $\begin{array}{r}4.4 x \\
10^{6}\end{array}$ & 20 & $\begin{array}{r}4.0 \mathrm{x} \\
10^{2}\end{array}$ & $\begin{array}{r}0.00 \\
1\end{array}$ & $\begin{array}{r}1.24 \mathrm{x} \\
10^{8}\end{array}$ & $\begin{array}{r}4.2 x \\
10^{7}\end{array}$ & $\begin{array}{r}33 \\
.8\end{array}$ & $2.4 \times 10$ & $\begin{array}{c}0.00 \\
2\end{array}$ \\
\hline $\begin{array}{l}F \\
L\end{array}$ & $\begin{array}{r}9.53 x \\
10^{7}\end{array}$ & $\begin{array}{l}3.24 \times 1 \\
0^{7}\end{array}$ & $\begin{array}{l}33 \\
.9\end{array}$ & $\begin{array}{l}2.5 \times 1 \\
0^{5}\end{array}$ & $\begin{array}{c}0 . \\
26\end{array}$ & $\begin{array}{r}1.64 x \\
10^{7}\end{array}$ & $\begin{array}{r}4.9 x \\
10^{6}\end{array}$ & 29 & $\begin{array}{r}3.8 \mathrm{x} \\
10^{3}\end{array}$ & $\begin{array}{r}0 . \\
02\end{array}$ & $\begin{array}{r}1.1 \times 1 \\
0^{8}\end{array}$ & $\begin{array}{r}3.88 x \\
10^{7}\end{array}$ & $\begin{array}{r}35 \\
.2\end{array}$ & $1.4 \times 10$ & $\begin{array}{c}0.00 \\
1\end{array}$ \\
\hline
\end{tabular}

Note: PW - Pond water, FE - Feed, SP - Spawn, FR - Fry, FL - Finger ling, NA - Total plate count on nutrient agar,

SAA - Total plate count on starch ampicillin agar, ONA - Total plate count on oxytetracycline agar, TC - Total count, \% - Percentage with respect to NA, N.D. - Not done

Table 2: Total, Ampicillin and Oxytetracycline resistant viable bacterial concentrations from adult fish

\begin{tabular}{|c|c|c|c|c|c|}
\hline \multirow{2}{*}{ Source } & \multicolumn{4}{|c|}{ VIABLE COUNT (CFU/mI OR CFU/gm) } \\
\cline { 2 - 6 } & \multirow{2}{*}{$\mathrm{NA}$} & \multicolumn{2}{|c|}{ SAA } & \multicolumn{2}{c|}{ ONA } \\
\cline { 3 - 6 } & & TC & $\%$ & TC & $\%$ \\
\hline AD1 & $1.04 \times 10^{6}$ & $3 \times 10^{5}$ & 28.84 & $4 \times 10^{3}$ & 0.38 \\
\hline AD2 & $1.84 \times 10^{\prime}$ & $1.12 \times 10^{\prime}$ & 60.86 & $6 \times 10^{4}$ & 0.32 \\
\hline AD3 & $2.4 \times 10^{8}$ & $3.2 \times 10^{\prime}$ & 13.33 & $1.56 \times 10^{4}$ & 0.0065 \\
\hline AD4 & $1.04 \times 10^{8}$ & $1.76 \times 10^{\prime}$ & 16.92 & $1.64 \times 10^{4}$ & 0.015 \\
\hline AD5 & $6.8 \times 10^{\prime}$ & $1.56 \times 10^{6}$ & 2.29 & $6.4 \times 10^{4}$ & 0.094 \\
\hline
\end{tabular}

Note: $A D$ - adult fish, NA - total plate count on nutrient agar, SAA - total plate count on starch Ampicillin agar,

ONA - total plate count on oxytetracycline agar, TC - total count, \% - percentage with respect to NA

Table 3: Source of Oxytetracycline resistant bacterial isolates from Indian major carps farms and adult fish

\begin{tabular}{|l|c|c|c|c|}
\hline \multirow{2}{*}{ Source } & \multicolumn{4}{|c|}{ Number of Strains } \\
\cline { 2 - 4 } & Farm I & Farm II & Farm III & Adult fishes \\
\hline Pond water & 7 & - & - & \\
\hline Feed & - & 6 & - & \multirow{2}{*}{12} \\
\hline Spawn & 9 & 5 & - & \\
\hline Fry & 6 & 2 & 4 & 12 \\
\hline Fingerlings & 5 & - & 10 & 12 \\
\hline TOTAL & 27 & 13 & & \\
\hline
\end{tabular}

Table 4: Frequency of Oxytetracycline-resistant bacterial isolates from Indian major carp's farms and adult fish

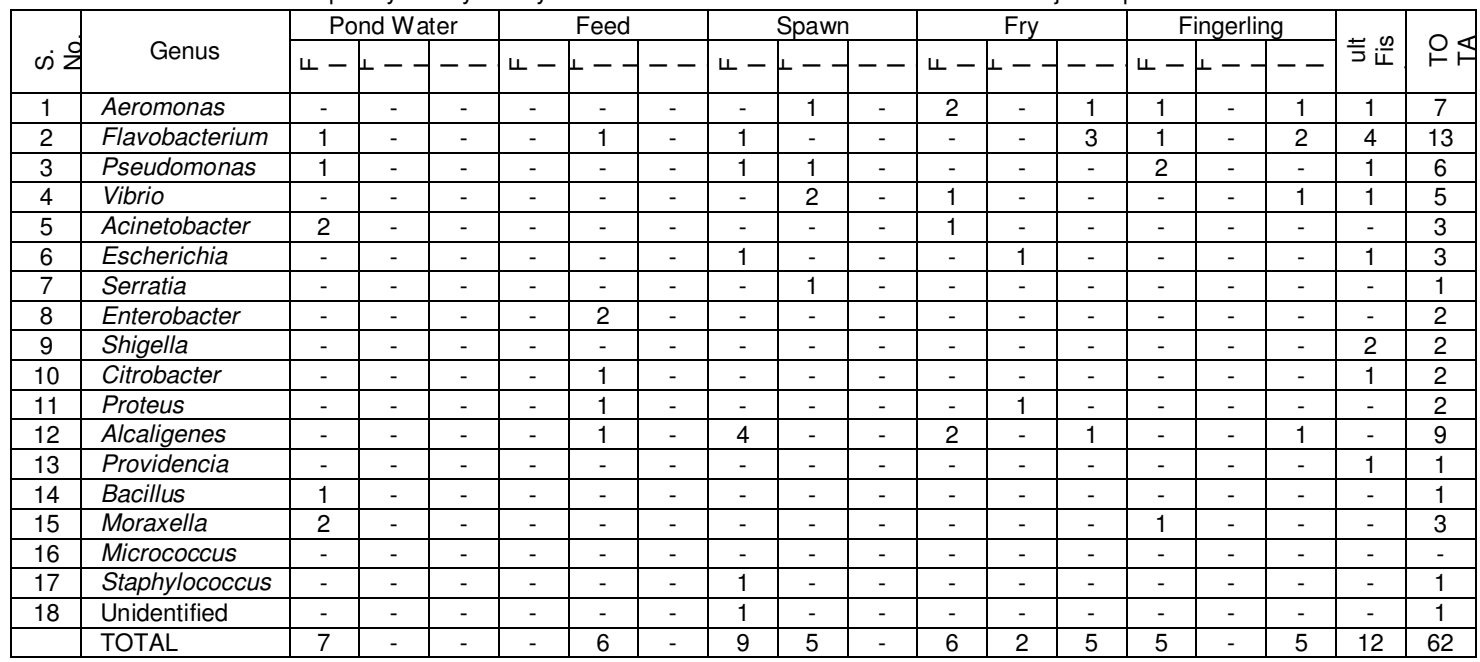

Note: FI - Farm I, FII - Farm II, FIII - Farm III. 
Table 5: Frequency of bacterial isolates from adult fish

\begin{tabular}{|c|c|c|c|c|c|c|c|}
\hline \multirow{2}{*}{ S.No. } & Genus & \multicolumn{5}{|c|}{ Adult Fish } & \multirow{2}{*}{ TOTAL } \\
\cline { 3 - 7 } & & AD1 & AD2 & AD3 & AD4 & AD5 & \\
\hline 1 & Aeromonas & 2 & - & 3 & 1 & - & 6 \\
\hline 2 & Pseudomonas & - & - & 1 & 4 & - & 5 \\
\hline 3 & Vibrio & - & - & 2 & 6 & - & 8 \\
\hline 4 & Flavo/Flexi & 1 & 4 & - & 8 & 2 & 15 \\
\hline 5 & Acinetobacter & - & - & - & - & - & - \\
\hline 6 & Escherichia & 1 & - & - & - & 1 & 2 \\
\hline 7 & Serratia & 1 & - & - & - & - & 1 \\
\hline 8 & Enterobacter & - & - & - & 1 & - & 1 \\
\hline 9 & Citrobacter & - & - & - & - & - & - \\
\hline 10 & Proteus & 1 & - & - & - & 1 & 2 \\
\hline 11 & Klebsiella & - & - & - & - & 3 & 3 \\
\hline 12 & Shigella & - & - & 2 & - & - & 2 \\
\hline 13 & Providencia & - & - & 1 & - & - & 1 \\
\hline 14 & Alcaligenes & - & - & - & - & - & - \\
\hline 15 & Moraxella & - & - & - & - & - & - \\
\hline 16 & Staphylococcus & - & - & - & - & - & - \\
\hline 17 & Micrococcus & - & - & - & - & - & - \\
\hline 18 & Streptococcus & - & - & 2 & - & - & 2 \\
\hline 19 & Bacillus & - & - & - & - & - & - \\
\hline 20 & Unidentified & - & - & - & - & - & - \\
\hline & TOTAL & 6 & 4 & 11 & 20 & 7 & 48 \\
\hline
\end{tabular}

Table 6: Source of bacterial strains recovered from Indian major carps farms

\begin{tabular}{|c|c|c|c|c|c|c|c|c|c|c|c|}
\hline \multirow{2}{*}{$\begin{array}{c}\text { S. } \\
\text { No. }\end{array}$} & Source & \multicolumn{9}{|c|}{ NUMBER OF STRAINS } & \multirow{2}{*}{ TOTAL } \\
\cline { 3 - 12 } & & \multicolumn{3}{|c|}{ FARM I } & \multicolumn{3}{|c|}{ FARM II } & \multicolumn{3}{c|}{ FARM III } & \\
\cline { 3 - 12 } & & NA & SAA & ONA & NA & SAA & ONA & NA & SAA & ONA & \\
\hline 1 & PW & 6 & 3 & 7 & 4 & 8 & - & 7 & 4 & - & 39 \\
\hline 2 & FE & 5 & 7 & - & 2 & 2 & 6 & - & - & - & 22 \\
\hline 3 & SP & 12 & 11 & 9 & 5 & 2 & 5 & - & 2 & - & 46 \\
\hline 4 & FR & 13 & 6 & 6 & 4 & 4 & 2 & 5 & 3 & 5 & 48 \\
\hline 5 & FL & 11 & 5 & 5 & 2 & - & - & 4 & 3 & 5 & 35 \\
\hline & TOTAL & 47 & 32 & 27 & 17 & 16 & 13 & 16 & 12 & 10 & 190 \\
\hline
\end{tabular}

Note: PW - Pond water; FE - Feed; SP - Spawn; FR - Fry; FL - Fingerling.

Table 7: Source of bacterial strains recovered from adult fishes

\begin{tabular}{|c|c|c|c|c|c|c|}
\hline & AD1 & AD2 & AD3 & AD4 & AD5 & TOTAL \\
\hline NA & 2 & 1 & 1 & 7 & - & 11 \\
\hline SAA & 3 & 2 & 3 & 10 & 7 & 25 \\
\hline ONA & 1 & 1 & 6 & 3 & 1 & 12 \\
\hline TOTAL & 6 & 4 & 10 & 20 & 8 & 48 \\
\hline
\end{tabular}

Table 8: Source and type of sample collected for different bacterial isolates from different farms

\begin{tabular}{|c|c|c|c|c|c|c|}
\hline $\begin{array}{c}\text { Source of } \\
\text { sample }\end{array}$ & \multicolumn{2}{|c|}{ Farm I } & \multicolumn{2}{c|}{ Farm II } & \multicolumn{2}{c|}{ Farm III } \\
\cline { 2 - 7 } & $\begin{array}{l}\text { No. of } \\
\text { samples }\end{array}$ & $\begin{array}{c}\text { No. of } \\
\text { isolates }\end{array}$ & $\begin{array}{l}\text { No. of } \\
\text { samples }\end{array}$ & $\begin{array}{c}\text { No. of } \\
\text { isolates }\end{array}$ & No.ofsamples & $\begin{array}{c}\text { No. of } \\
\text { isolates }\end{array}$ \\
\hline $\begin{array}{c}\text { Pond } \\
\text { water }\end{array}$ & 3 & 16 & 2 & 12 & 2 & 11 \\
\hline Feed & 2 & 12 & 1 & 10 & - & 0 \\
\hline Spawn & 3 & 32 & 2 & 12 & 1 & 2 \\
\hline Fry & 3 & 25 & 2 & 10 & 2 & 13 \\
\hline Finger ling & 3 & 21 & 1 & 2 & 2 & 12 \\
\hline Total & 14 & 106 & 8 & 46 & 7 & 38 \\
\hline
\end{tabular}


Table 9: Source and type of sample collected for different bacterial isolates from adult fish

\begin{tabular}{|c|c|c|c|c|c|}
\hline Source & AD1 & AD2 & AD3 & AD4 & AD5 \\
\hline No. of isolates & 6 & 4 & 11 & 20 & 7 \\
\hline
\end{tabular}

Note: AD1-5 - Adult fishes

Table 10: Antibiotic sensitivity pattern of different genus

\begin{tabular}{|c|c|c|c|c|}
\hline S.No. & Genus & Resistant & Intermediate & Sensitive \\
\hline 1 & Vibrio & $\mathrm{O}, \mathrm{Nv} \& \mathrm{Nr}$ & - & $\mathrm{Cf}, \mathrm{C} \& \mathrm{G}$ \\
\hline 2 & $\begin{array}{c}\text { Aeromonas } \\
\text { hydrophila }\end{array}$ & $\mathrm{Nv}$ & $\mathrm{Nr}$ & $\mathrm{O}, \mathrm{Cf}, \mathrm{C} \& \mathrm{G}$ \\
\hline 3 & Aeromonas sobria & - & $\mathrm{O} \& \mathrm{Nr}$ & $\mathrm{Cf}, \mathrm{C}, \mathrm{G} \& \mathrm{Nr}$ \\
\hline 4 & Pseudomonas & $\mathrm{Co}$ & $\mathrm{O}$ & $\mathrm{Cf}, \mathrm{C}, \mathrm{G} \& \mathrm{Nr}$ \\
\hline 5 & Flavobacterium & $\mathrm{O} \& \mathrm{Nv}$ & - & $\mathrm{Cf}, \mathrm{C}, \mathrm{G} \& \mathrm{Nr}$ \\
\hline 6 & Escherichia & $\mathrm{Co} \& \mathrm{C}$ & $\mathrm{O}$ & $\mathrm{Cf}, \mathrm{G} \& \mathrm{Nr}$ \\
\hline 7 & Serratia & $\mathrm{O} \& \mathrm{Nv}$ & $\mathrm{Nr}$ & $\mathrm{Cf}, \mathrm{C}, \mathrm{G} \&$ Co \\
\hline 8 & Klebsiella & $\mathrm{Nr}$ & $\mathrm{C}$ & $\mathrm{O}, \mathrm{Cf}, \mathrm{Co} \& \mathrm{G}$ \\
\hline 9 & Shigiella & $\mathrm{Nr}$ & - & $\mathrm{O}, \mathrm{Cf}, \mathrm{CO}, \mathrm{C} \&$ \\
$\mathrm{G}$ & - & $\mathrm{O}, \mathrm{G} \& \mathrm{Nr}$ & $\mathrm{Cf}, \mathrm{Co} \& \mathrm{C}$ \\
\hline 10 & Enterobacter & $\mathrm{O} \& \mathrm{Nr}$ & - & $\mathrm{Cf}, \mathrm{Co}, \mathrm{C} \& \mathrm{C}$ \\
\hline 11 & Citrobacter & $\mathrm{O} \& \mathrm{Nr}$ & $\mathrm{Co}$ & $\mathrm{Cf}, \mathrm{C} \mathrm{\&} \mathrm{G}$ \\
\hline 12 & Provendencia &
\end{tabular}

Note: C - Chloramphenicol, Cf - Ciprofloxacin, Co - CoTrimaxazole, G - Gentamicin, $\mathrm{Nr}$ - Nitrofurazone, $\mathrm{Nv}$-Novobiocin, O - Oxytetracycline.
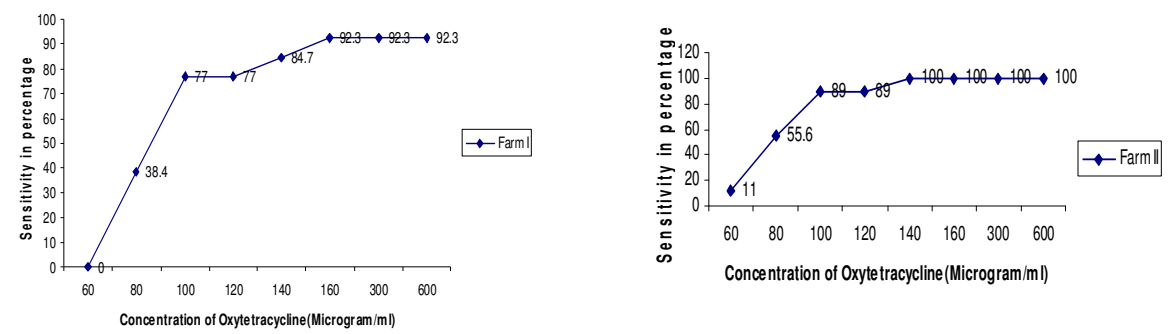

Fig 1: Minimum Inhibitory Concentration of oxytetracycline in Farm I Fig 2: Minimum Inhibitory Concentration of oxytetracycline in Farm II

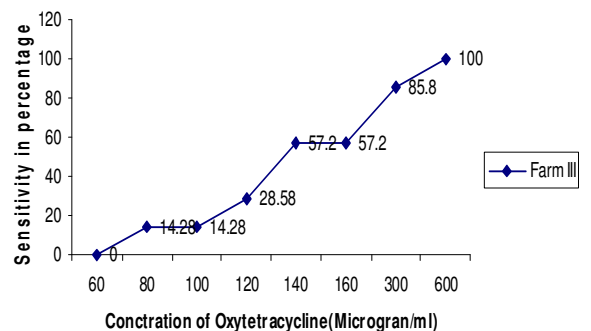

Fig 3: Minimum Inhibitory Concentration of oxytetracycline in Farm III

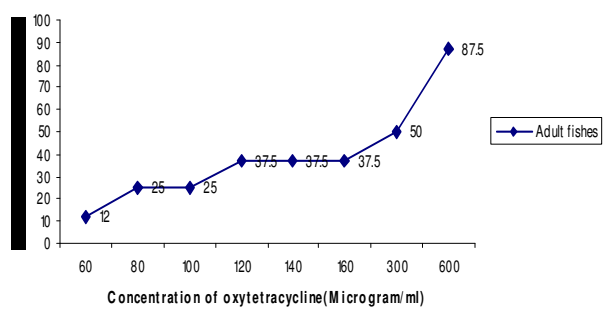

Fig 4: Minimum Inhibitory Concentration of oxytetracycline in Adult fishes

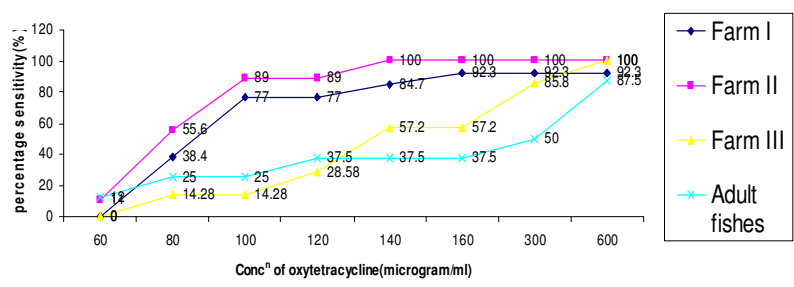

Fig 5: Minimum Inhibitory Concentration of oxytetracycline in Farm I, Farm II, Farm III and Adult fishes 